\author{
K. Hutchinson ${ }^{1,5}$, C.P. Kerley ${ }^{3}$, J. Faul ${ }^{2}$, P. Greally 3 , D. Coghlan ${ }^{4}$, M. Louw ${ }^{1}$, \\ B. ELNAZIR ${ }^{3}$, Y. ROCHEV ${ }^{5,6}$
}

\title{
Vitamin D receptor variants and uncontrolled asthma
}

\author{
${ }^{1}$ Biomnis Ireland, Sandyford, Dublin 18, Ireland \\ ${ }^{2}$ Asthma Research Centre, Connolly Hospital, Dublin 15, Ireland \\ ${ }^{3}$ Paediatric Respiratory Department, National Children's Hospital, Dublin, Ireland \\ ${ }^{4}$ Department of Paediatric Medicine, National Children's Hospital, Dublin, Ireland \\ ${ }^{5}$ School of Chemistry, National University of Ireland, Galway, Ireland \\ ${ }^{6}$ Sechenov First Moscow State Medical University, Institute for Regenerative Medicine, Moscow, Russia
}

\section{KEY WORDS}

vitamin D receptor; asthma;

polymorphisms; Interleukin-10;

biomarkers

\section{Corresponding author}

Katrina Hutchinson

Biomnis, Sandyford, Dublin 18, Ireland

ORCID: orcid.org/0000-0002-4293-7526

Phone:+ 35312958545

Fax: +35312958550

E-mail: katrina.hutchinson@eurofins-biomnis.ie

Doi

10.23822/EurAnnACI.1764-1489.46

\begin{abstract}
Summary
Background. Asthma is a common childhood respiratory disease, affecting around 20\% of Irish children. In other populations, vitamin D receptor (VDR) polymorphisms have been associated with asthma risk. We aimed to investigate the association between 2 VDR polymorphisms and uncontrolled paediatric asthma. Methods. 44 asthmatic children and 57 healthy volunteers were studied. The VDR TaqI gene variant in exon 9 (T/C) (rs731236) and ApaI (rs7975232) in intron 8 (C/T) were determined, using TaqMan ${ }^{\circledR}$ Assays. The lung function, serum 25-hydroxyvitamin D (25OHD) levels and other biomarkers of allergy, immunity, airway and systemic inflammation were assessed. Results. The distribution of $T$ and $C$ alleles and genotype frequencies differed significantly between asthmatics and controls for both polymorphisms ( $p<0.05)$. A significant association was found between both TaqI (OR $=2.37,95 \% C I(1.27-4.45), p=0.007)$ and ApaI polymorphisms, and asthma risk (OR $=2.93,95 \% C I(1.62-5.3), p=0.0004)$. No association was observed between genotypes and $25 \mathrm{OHD}$ levels, lung function and other biomarkers, with the exception of Interleukin-10 (IL-10) and white blood cells count (WBC). IL-10 levels were lower in asthmatics with TC genotype for TaqI polymorphism $(p<0.01)$ and were higher in patients with TT genotype for ApaI $(p<0.01)$. WBC were higher in patients with TC and CC genotypes for TaqI $(p<0.05)$ and lower in TT genotype for ApaI ( $p<0.05)$. Conclusion. TaqI and ApaI polymorphisms are associated with asthma in Irish children. Further studies are warranted to investigate the importance of decreased IL-10 levels in paediatric asthmatics with specific genotypes.
\end{abstract}

\section{Introduction}

Asthma is a chronic heterogeneous respiratory disease with both genetic and environmental components. It is the most common chronic disease in Ireland, affecting about $20 \%$ of children. Vitamin D receptor (VDR) polymorphisms are associated with asthma and allergy susceptibility $(1,2)$. VDR is widely expressed in human lungs throughout the full epithelial layer, as is 1a-hydroxylase (3), which is responsible for the formation of the active vitamin $\mathrm{D}$ metabolite, 1a-calcitriol $\left(1 \alpha, 25(\mathrm{OH})_{2} \mathrm{D}_{3}\right)$. Vitamin
$\mathrm{D}$ might influence the regulation of adaptive and innate immune functions, and the proliferation and differentiation of many cell types (4), and it may influence airway remodelling (5).

Vitamin D deficiency (VDD) is common worldwide, particularly in children $(6,7)$, and several medical conditions are associated with low serum levels of 25-hydroxyvitamin D (25OHD), including asthma $(8,9)$. It remains controversial whether vitamin $\mathrm{D}$ supplementation, which is broadly recommended for bone health, has significant effects in children with asthma. In our recent study of Vitamin D supplementation in paediatric asthma in Ireland, 50\% 
of the children were vitamin D deficient (25OHD levels $<50$ nmo1/L) (10), but Vitamin D supplementation led to improved asthma control only in selected children, suggesting that VDR genetic variants may influence the effects of Vitamin D on the asthmatic airway. Some children who did well during the study have low vitamin D levels at the baseline, and some have high (25OHD levels $>50 \mathrm{nmol} / \mathrm{L}$ ), but only $44 \%$ of patients achieved $25 \mathrm{OHD}$ levels over $100 \mathrm{nmol} / \mathrm{L}$ after supplementation. We used blood samples from the study mentioned above (10) for our genetic investigations. The VDR binds to its ligand $1 \alpha, 25(\mathrm{OH})_{2} \mathrm{D}_{3}$. It belongs to the nuclear receptors family of trans-acting transcriptional regulatory factors and it shows a sequence similarity to the thyroid's and steroids' hormone receptors. The VDR gene is known as a pleiotropic gene, and is associated with numerous conditions - such as autoimmune, inflammatory, and allergic diseases, including asthma. The gene maps to chromosome 12q13.11 (11), contains nine exons with at least six isoforms of exon 1, encodes a 427 amino acid protein.

Han et al. suggested that VDR polymorphisms, rather than vitamin D levels, could be developed as biomarkers for asthma susceptibility (12). The association between genetic variants of VDR and paediatric asthma has been studied in different ethnic groups (13-16). Over 900 genes may be transcribed by VDR $(17,18)$. Jolliffe et al. suggested that variation in VDR might prove a more important determinant of the expression of diseases like asthma than circulating 25OHD (19).

Several single nucleotide polymorphisms (SNPs) in the VDR gene have been discovered, including ApaI and TaqI, which are named after the corresponding restriction enzymes used in restriction fragment length polymorphism (RFLP) analysis.

In this pilot study we aimed, first, to determine the VDR gene variants TaqI in exon $9(\mathrm{~T} / \mathrm{C})$ and $\mathrm{ApaI}$ in intron $8(\mathrm{C} / \mathrm{T})$ in symptomatic paediatric asthmatics, and in healthy volunteers in Ireland; secondly, to investigate the impact of these polymorphisms in asthma susceptibility in relation to lung function, $25 \mathrm{OHD}$, and other indices; and finally, to examine the possibility of using these polymorphisms as potential biomarkers for asthma.

\section{Methods}

The study was carried out at the National Children's Hospital, Tallaght, James Connolly Memorial Hospital Dublin, and Biomnis Ireland (Dublin, latitude, $53^{\circ} \mathrm{N}$ ) after receiving institutional review board approval from both hospitals, and having obtained consent from parents, guardians and the healthy adults who were involved.

\section{Subjects and study design}

Asthmatic children were recruited from paediatric respiratory out-patient clinics for a vitamin D supplementation study (the tri- al was registered at ClinicalTrials.gov. Identifier: NCT02428322) (10). Our 44 subjects were Caucasian, aged 6-16, and established on anti-asthmatic medication with previous diagnosis of uncontrolled asthma according to the Global Initiative for Asthma 2011 guidelines (20). The healthy 57 subjects had no personal or family history of asthma or other respiratory illnesses, or bone, articular, renal or any other chronic diseases. Controls (healthy subjects) were recruited for this study of VDR. We examined two RFLPs in the VDR gene in both groups. We also studied the relationship between the polymorphisms and different biomarkers and subjective and objective asthma parameters in a cohort of asthmatic children. All these patients were known uncontrolled asthmatics on established anti-asthma therapy. A clinical nurse specialist assessed adherence to anti-asthma medication. Spirometry was carried out according to the American Thoracic Society / European Respiratory Society, with the spirometry module of the V-max Encore System (Carefusion). Results were presented as a percentage of predicted values (21). Subjective asthma control and quality of life scores were calculated. They combine the Global Initiative for Asthma score (GINA), the Childhood Asthma Control Test (C-ACT), and the Paediatric Asthma Quality of Life Questionnaire (PAQLQ).

\section{Statistical analysis}

Allele and genotype frequencies were calculated by direct counting. The $\chi^{2}$ and (when the expected count was lower than 5) Fisher's exact tests were used to compare frequencies between cases and controls, and also for Hardy-Weinberg equilibrium determination. In investigating genotypic associations, odd ratios (OR) were reported for the allelic distribution. For group comparisons for biomarkers we used the t-test and Kruskal-Wallis test. Mean for biomarkers' values of genotypes in groups were compared with one-way ANOVA and Tukey's multiple comparisons test. P value $<0.05$ counts as significant. We used GraphPad Prism 5, Version 5.01 software.

\section{Laboratory Methods}

\section{Biochemistry and FBCs}

Venous blood was collected into BD Vacutainer tubes ${ }^{\circledR}$ containing EDTA and no additive. Whole blood with EDTA was analysed for full blood count (FBC) using an automated analyser Sysmex XE-2100D (Sysmex America, Mundelein, IL 60060 USA) on the day of collection, and samples were kept for DNA extraction. Additional blood in non-gel serum tubes was centrifuged at 4000 RCF for 10 minutes, aliquoted, and frozen to -80 ${ }^{\circ} \mathrm{C}$ until further analysis.

Total serum 25OHD levels were analysed on Abbott Architect ci8200 (Abbott Laboratories, Abbott Park, Illinois, USA) using 
chemiluminescent microparticle immunoassay (CMIA) method with between-run and within-run CVs $<6 \%$. The assay is VDSP (Vitamin D Standardisation Programme) certified. It successfully passed the performance criterion of $\pm 5 \%$ mean bias of the Centres of Disease Control (CDC) and University of Ghent Vitamin D2 and D3 Reference Method with an overall imprecision of $<10 \%$ over the concentration range of 22-275 $\mathrm{nmol} / \mathrm{L}$ for total $25 \mathrm{OHD}$.

We divided 25OHD levels into two groups, based on the most up-to-date Institute of Medicine recommendations, according to which $<50 \mathrm{nmol} / \mathrm{L}$ indicates VDD and $>50 \mathrm{nmol} / \mathrm{L}$ indicates vitamin $\mathrm{D}$ sufficiency (VDS).

Serum concentrations of intact parathyroid hormone (PTH), albumin, total calcium, alkaline phosphatases, phosphate, total $\operatorname{IgE}$, immunoglobulin $\mathrm{A}$, and high sensitivity $\mathrm{C}$ reactive protein (hsCRP) were measured, using commercially available diagnostic kits on the automated analyser Abbott Architect ci8200. The between-run and within-run CVs for these assays ranged between $1 \%$ and $6 \%$.

Eosinophil cationic protein (ECP) was analysed on the Phadia 250, using fluorescent enzymeimmunoassays (ImmunoCAP Technology) with a between-run CV $<7 \%$ and minimum detectable level of $2 \mathrm{ug} / \mathrm{L}$ (normal range: $11.1-13.3 \mathrm{ug} / \mathrm{L}$ ).

Serum levels of Interleukin-10 (IL-10) and CAMP (cathelicidin antimicrobial peptide) were determined by human enzyme-linked immunosorbent assay method (ELISA kit assays, Damastown, Dublin 15), with intra- and interassay $\mathrm{CV}<8 \%$. All assays were analysed with kits of the same lot number.

\section{Genotyping of TaqI and ApaI polymorphisms}

DNA isolation was performed on Maxwell 16 System (Promega Corporation, Madison, WI, USA). The outcome of this technique was high molecular weight DNA ( $>20 \mathrm{~kb})$ that had no traces of RNA contamination and had a 260/280 absorbance ratio $>1.7$. The isolated DNA was stored at $-20^{\circ} \mathrm{C}$ until required for analysis. Based on a candidate gene approach, we selected two SNPs of the VDR gene, which have a functional impact on gene expression and function. Both polymorphisms have been widely studied in different populations in relation to various medical conditions, including asthma (1,2,13-15).

Genotyping of TaqI (rs731236, assay number C_2404008_10) and of ApaI (rs7975232, assay number C_28977635_10) was performed using TaqMan ${ }^{\circledR}$ SNP Genotyping Assay. Real Time PCR was carried out using $5 \mu \mathrm{l}$ TaqMan ${ }^{\circledR}$ Genotyping Master Mix, $0.25 \mu \mathrm{l} \mathrm{TaqMan}{ }^{\circledR}$ SNP Genotyping Assay (TaqMan probes) (40×), $3.75 \mu$ l Dnase Free Water and $1 \mu$ DNA (1-10 $\mathrm{ng})$. The final reaction volume was $10 \mu \mathrm{l}$. The thermal conditions of Real Time PCR were: initial denaturing at $95^{\circ} \mathrm{C}$ for 10 min; 40 cycles of $95^{\circ} \mathrm{C}$ for $15 \mathrm{sec}$ (denaturing) and $60^{\circ} \mathrm{C}$ for 1 min (annealing / extension). Approximately $20 \%$ of the samples from the first run were selected randomly for confirmation of the results, and $100 \%$ of them matched. The genotyping success rates for two SNPs were $>99 \%$.

SDS 2.3 software was used for allelic discrimination (Applied Biosystems).

All the materials were used in the TaqMan ${ }^{\circledR}$ SNP Genotyping Assay (ABI), in compliance with the manufacturer's instructions and with information supplied on the Applied Biosystems website http://www.appliedbiosystems.com.

The laboratory where the analyses were performed is accredited against ISO 15189.

\section{Results}

44 uncontrolled paediatric asthmatics (23 male, mean 8.7 years, mean BMI $19.9 \mathrm{~kg} / \mathrm{m}^{2}$ ) completed all baseline measures. Their asthma was uncontrolled, based on poor symptom control, and was assessed by the Childhood Asthma Control Test (C-ACT). The median GINA score was 3 with a minimum of 1 and maximum of 5. 100 per cent of patients were on inhaled corticosteroids. More detailed clinical information for the patients has been provided in our previous paper (10). Mean 25OHD was $51 \mathrm{nmol} / \mathrm{l}$ (range: $24-80 \mathrm{nmol} / \mathrm{l}$ ) and 22 children were VDD, while the other 22 were VDS. 25OHD levels and lung function parameters $\left(\mathrm{FEV}_{1}\right.$ and $\left.\mathrm{FVC} \%\right)$ were significantly higher in VDS vs. VDD patients ( $<0.001$ and $\mathrm{p}=0.03$, respectively) (table 1). Subjective asthma parameters and biomarkers, such as C-ACT, PAQLQ, ECP and hsCRP did not show any significant difference. IgE was an exception (figure 1). Consistent with

Figure 1 - Average of Total IgE level in VDS and VDD groups of 44 uncontrolled asthmatic children according to $25 \mathrm{OHD}$ levels of $<50$ and $>50 \mathrm{nmol} / \mathrm{L}\left(r^{2}=0.18, p=0.0046^{*}\right)$.

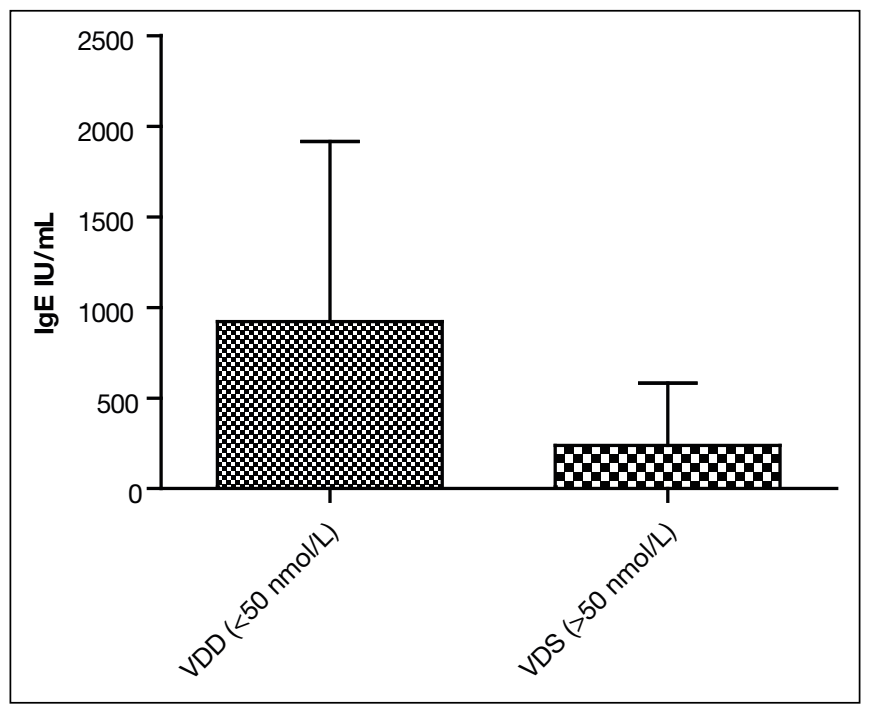


Figure 2 - Relationship between serum $250 H D$ levels and serum total $\operatorname{IgE}\left(r^{2}=0.12, p=0.023^{*}\right)$ in 44 uncontrolled asthmatic children.

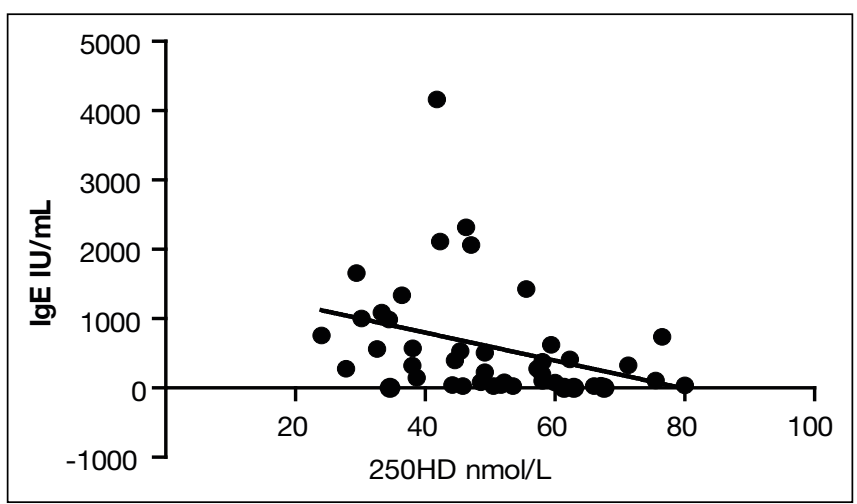

previous reports, negative correlation was found between $\operatorname{IgE}$ and 25OHD levels ( $\mathrm{p}=0.023)$ in all patients studied (figure 2). We found that the distribution of $\mathrm{T}$ and $\mathrm{C}$ alleles and genotype frequencies varied significantly between asthmatics and controls for both polymorphisms $(\mathrm{p}<0.05)$ (table 2,3$)$. The alleles' frequencies were significantly different, as shown by $37 \%$ prevalence of $\mathrm{C}$ allele (TaqI) and 52\% prevalence of $\mathrm{T}$ allele (ApaI) in asthmatic patients, versus $20 \%$ and $26 \%$ in the controls (p $=0.007, \mathrm{p}=0.0004)$. Children carrying the $\mathrm{C}$ allele for TaqI

Figure 3 - Average WBC levels in uncontrolled asthmatic children according to TaqI genotypes. (Tukey's Multiple Comparison Test: TT vs TC and for TT vs CC, $p<0.05^{*}$ ).

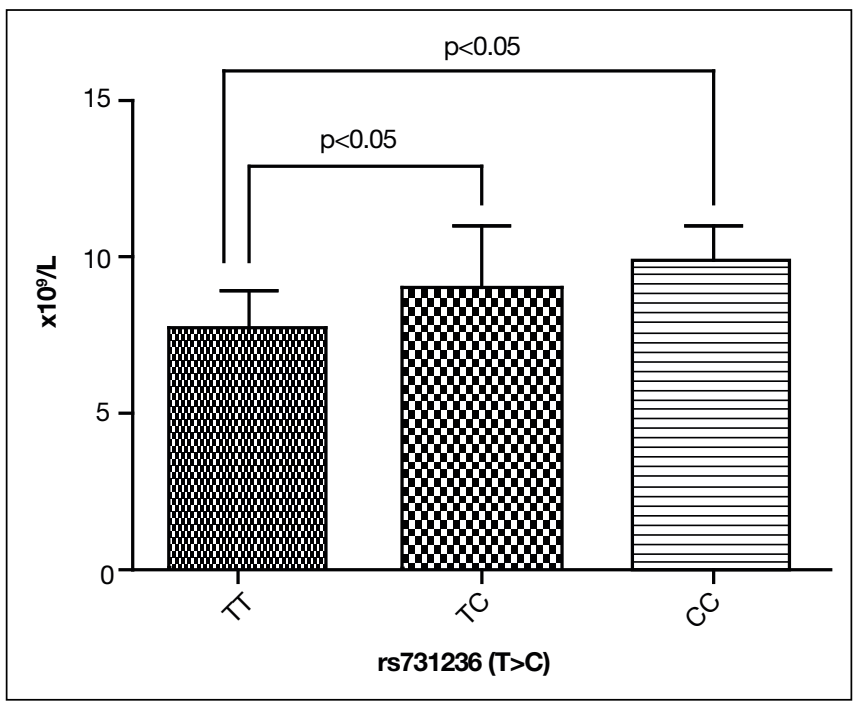

Figure 4 - Average WBC levels in uncontrolled asthmatic children according to ApaI genotypes. (Tukey's Multiple Comparison Test: TT vs $C C, p<0.05^{*}$ ).

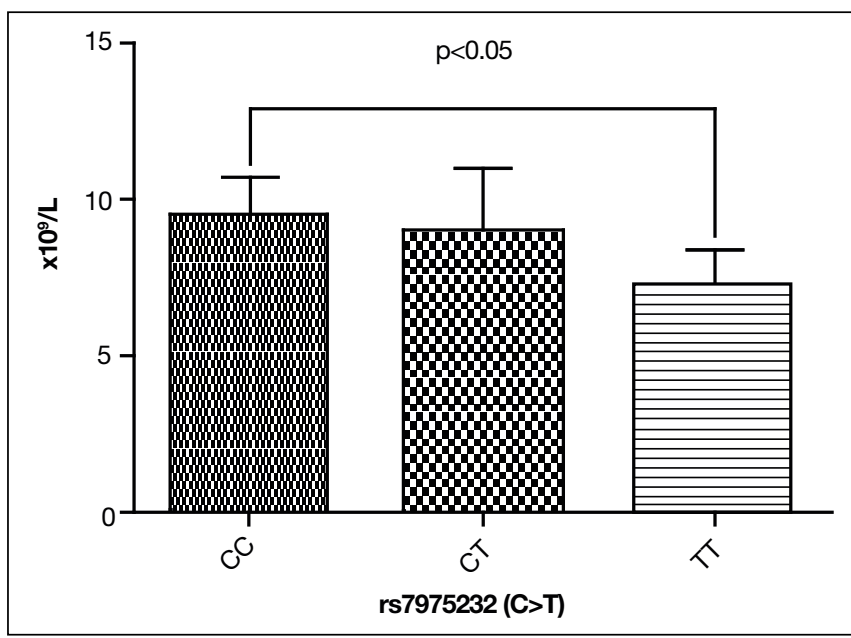

are 2.37 times more likely to develop asthma $(\mathrm{OR}=2.37,95 \%$ CI (1.27-4.45)) and children carrying the risk $\mathrm{T}$ allele for ApaI are 2.93 times more susceptible for asthma development $(\mathrm{OR}=$ 2.93, 95\% CI (1.62-5.3)) than healthy individuals.

Both cases and controls were in Hardy-Weinberg equilibrium for both ApaI and TaqI: $p>0.2$ in three analyses, with the exception for TaqI in healthy individuals. The two SNPs were in linkage disequilibrium in cases $\left(\mathrm{D}=1.000, \mathrm{r}^{2}=0.633\right)$ but not in controls $\left(\mathrm{D}=0.596, \mathrm{r}^{2}=0.25\right)$. ApaI C allele was linked to TaqI C, and ApaI T to TaqI T in asthmatic children.

In relation to polymorphisms study in uncontrolled asthmatics, we found no association between genotypes and lung function, serum 25OHD levels and other biomarkers, including IgE, ECP, CAMP and hsCRP - except IL-10 and white blood cells count (WBC). IL-10 levels were significantly low in asthmatics with TC genotype for TaqI $(\mathrm{p}<0.003)$ and significantly high in patients with TT genotype for ApaI polymorphism ( $\mathrm{p}<0.005)$ (tables 4, 5). WBC was significantly high in patients with TC and CC genotypes for TaqI and significantly low in TT genotype for ApaI (figure 3, 4). There was a trend toward greater Neutrophils count, respectively $(\mathrm{p}=0.05)$ for TaqI, and ( $\mathrm{p}$ $=0.08$ ) for patients with CC genotype for ApaI. Only two of our children were obese $\left(\mathrm{BMI}>30 \mathrm{~kg} / \mathrm{m}^{2}\right)$. Both children were VDD at the baseline. After supplementation, an improvement in asthma condition was observed only in the patient with TT genotype for TaqI and ApaI polymorphisms. The other child, who had TC genotypes for both polymorphisms, registered no improvement.

Our haplotype analysis for two polymorphisms showed that TT and CC haplotypes were significantly associated with un- 
Table 1- Baseline data for VDD and VDS groups (44 asthmatics).

\begin{tabular}{|c|c|c|c|}
\hline & $<50 \mathrm{nmol} / \mathrm{L}(\mathrm{VDD})$ & > $50 \mathrm{nmol} / \mathrm{L}$ (VDS) & p value \\
\hline $\mathrm{n}$ (patients) & 22 & 22 & \\
\hline \multicolumn{4}{|c|}{ Subjective parameters } \\
\hline C-ACT (0-27) & $17 \pm 5$ & $17 \pm 5$ & 0.42 \\
\hline PAQLQ (0-91) & $64 \pm 18$ & $72 \pm 17$ & 0.07 \\
\hline VIDSun & $3 \pm 1$ & $4 \pm 1$ & $0.012^{*}$ \\
\hline \multicolumn{4}{|c|}{ Objective parameters } \\
\hline FEV1\% & $93.6 \pm 13.1$ & $101.9 \pm 15.1$ & $0.03^{*}$ \\
\hline FVC\% & $88.9 \pm 13.9$ & $96.1 \pm 9.2$ & $0.03^{*}$ \\
\hline $25(\mathrm{OH}) \mathrm{D}(\mathrm{nmol} / \mathrm{L})$ & $39.6 \pm 7.4$ & $62.2 \pm 8.2$ & $<0.001^{*}$ \\
\hline $\operatorname{IgE}(\mathrm{IU} / \mathrm{L})$ & $960 \pm 1000$ & $232 \pm 336$ & $0.001^{*}$ \\
\hline
\end{tabular}

Data shown as mean \pm SD. PAQLQ = paediatric quality of life questionnaire; C-ACT = childhood asthma control test; VIDSun = Vitamin D and Sun questionnaire. *denotes statistically significant.

Table 2 - Genotypic association analysis of VDR RFLPs (restriction fragment length polymorphisms) TaqI and ApaI between paediatric asthmatic patients and control individuals.

\begin{tabular}{|c|c|c|c|c|c|}
\hline Enzyme analysis & Patients (44) & Controls (57) & $\begin{array}{l}\text { Multiple comparison } \\
\text { p value }^{1}\end{array}$ & $x^{2}$ & $p$ value \\
\hline \multicolumn{6}{|l|}{ TaqI Genotypes } \\
\hline $\mathrm{TT}$ & $17(38 \%)$ & $34(60 \%)$ & & & \\
\hline CT & $21(48 \%)$ & $23(40 \%)$ & & 10.25 & $0.006^{*}$ \\
\hline $\mathrm{CC}$ & $6(14 \%)$ & $0(0 \%)$ & & & \\
\hline TT/CT & $17 / 21$ & $34 / 23$ & $0.2^{1}$ & & \\
\hline TT/CC & $17 / 6$ & $34 / 0$ & $0.003^{1}$ & & \\
\hline CT/CC & $21 / 6$ & $23 / 0$ & $0.025^{1}$ & & \\
\hline \multicolumn{6}{|l|}{ ApaI Genotypes } \\
\hline TT & $11(25 \%)$ & $5(9 \%)$ & & & \\
\hline $\mathrm{CT}$ & $23(52 \%)$ & $20(35 \%)$ & & 18.82 & $0.0001^{*}$ \\
\hline $\mathrm{CC}$ & $10(23 \%)$ & $32(56 \%)$ & & & \\
\hline TT/CT & $11 / 23$ & $5 / 20$ & $0.38^{1}$ & & \\
\hline TT/CC & $11 / 10$ & $5 / 32$ & $0.002^{1}$ & & \\
\hline $\mathrm{CT} / \mathrm{CC}$ & $23 / 10$ & $20 / 32$ & $0.007^{1}$ & & \\
\hline
\end{tabular}

Data are: number $(\%) ;{ }^{*} \mathrm{p}<0.05$ is considered significant; ${ }^{1}$ Fisher's exact test. 
Table 3 - Allelic association analysis of VDR RFLPs TaqI $(T>C)$ and ApaI $(C>T)$ between uncontrolled paediatric asthmatic patients and control individuals.

\begin{tabular}{|c|c|c|c|c|}
\hline & Patients (44) & Controls (57) & OR $(95 \% \mathrm{CI})$ & p value \\
\hline \multicolumn{5}{|c|}{ TaqI allelic association } \\
\hline $\mathrm{T}$ & $55(63 \%)$ & $91(80 \%)$ & & \\
\hline \multicolumn{5}{|c|}{ ApaI allelic association } \\
\hline $\mathrm{T}$ & $45(52 \%)$ & $30(26 \%)$ & $2.93(1.62-5.3)$ & $0.0004^{*}$ \\
\hline
\end{tabular}

Data are: number (\%); OR = odds ratio; $95 \% \mathrm{CI}$ (in parentheses); *denotes statistically significant.

Table 4 - Relationship between serum IL-10 and TaqI (T>C) VDR RFLP (restriction fragment length polymorphism) genotypes in uncontrolled peadiatric asthmatics.

\begin{tabular}{|c|c|c|c|c|c|c|c|}
\hline \multicolumn{4}{|c|}{ Serum IL-10 pg/mL } & \multicolumn{4}{|c|}{ Sig. } \\
\hline Taq-I RFLP & $\mathrm{n}$ & mean & SD & $\mathrm{p}$ value & CC vs.TT & CC vs.TC & TT vs.TC \\
\hline $\mathrm{TT}$ & 16 & 135 & 47.9 & $\mathrm{p}=0.046^{*}$ & $\mathrm{~ns}$ & $\mathrm{~ns}$ & $\mathrm{p}=0.0026^{*}$ \\
\hline $\mathrm{CC}$ & 6 & 106 & 47.7 & & & & \\
\hline
\end{tabular}

$\mathrm{n}=$ number of subjects; $\mathrm{SD}=$ standard deviation; $\mathrm{p}<0.05$ is considered significant; Sig. refers to difference between means of homozygotes and heterozygotes (CC vs. TC), of the homozygotes and heterozygotes (TT vs. TC); ns = non-significant; *denotes statistically significant.

Table 5 - Relationship between serum IL-10 and ApaI (C > T) VDR RFLP (restriction fragment length polymorphism) genotypes in uncontrolled peadiatric asthmatics.

\begin{tabular}{|c|c|c|c|c|c|c|c|}
\hline \multicolumn{4}{|c|}{ Serum IL-10 pg/mL } & \multicolumn{4}{|c|}{ Sig. } \\
\hline Apa-I RFLP & $\mathrm{n}$ & mean & SD & $\mathrm{p}$ value & CC vs.TT & CC vs. CT & TT vs. CT \\
\hline TT & 10 & 154.8 & 45.5 & $\mathrm{p}=0.0053^{*}$ & $0.0163^{*}$ & $\mathrm{~ns}$ & $\mathrm{p}=0.0015^{*}$ \\
\hline CT & 22 & 95.3 & 25.4 & & & & \\
\hline $\mathrm{CC}$ & 10 & 103.0 & 41.8 & & & & \\
\hline
\end{tabular}

$\mathrm{n}=$ number of subjects; $\mathrm{SD}=$ standard deviation; $\mathrm{p}<0.05$ is considered significant; Sig. refers to difference between means of homozygotes and heterozygotes (CC vs. CT), of the homozygotes and heterozygotes (TT vs. CT); ns = non-significant; ${ }^{*}$ denotes statistically significant.

controlled asthma $(\mathrm{OR}=40.26,95 \% \mathrm{CI}(5.27-307.79), \mathrm{p}<$ 0.001, and OR 43.74 (95\% CI: $(4.87-393.20)$, p < 0.001, respectively).

\section{Discussion}

In our pilot study we examined 25OHD levels and asthma symptom control in relation to TaqI and ApaI VDR polymorphisms in Irish children with uncontrolled asthma. We found a significant association between TaqI and ApaI SNPs and susceptibility to uncontrolled paediatric asthma.

The results of our work on the associations between the two polymorphisms examined and asthma agree with other studies $(14,22)$ in which TaqI has been linked with asthma in paediatric patients. We also found an association between ApaI and asthma susceptibility. Children carrying the risk T allele for ApaI are nearly 3 times more susceptible to asthma. These findings 
agree with studies by Saadi et al. (23) and Iordanidou et al. (2); the latter showed that ApaI "a" allele was also associated with improved asthma control in children.

The TaqI (rs731236, c.1056T > C, p.Ile352Ile) is a synonymous polymorphism at codon 352 (isoleucine) of the gene, and this $\mathrm{T}>\mathrm{C}$ alteration does not result in amino acid sequence change $(24,25)$. The ApaI (rs7975232, c.1025-49G > T) is located in the intron 8 of the VDR gene (17). The two tested polymorphisms do not cause any structural changes of the VDR protein, but they are linked with other functional SNPs and may take part in a complex gene network enhancing or inhibiting the expression of VDR target genes.

The ApaI and TaqI polymorphisms are located at the 3' end of the gene and are near the regulatory 3 ' untranslated region (3'-UTR) of mRNA. This indicates that they have the potential to alter splicing regulation. When the ApaI and TaqI SNPs are found in specific haplotypes, they affect VDR mRNA stability and the rate of transcription, and this may result in altered protein expression (24-28). For example, in our study both SNPs were in linkage disequilibrium in paediatric asthmatics, but not in healthy volunteers.

Alternatively, epigenetic modifications in the VDR gene can suppress VDR transcription. In a study on tuberculosis susceptibility in lymphoblastoid cell lines, Andraos et al. have demonstrated that the TaqI variant resides on a CpG island and the $\mathrm{C}$ allele is always methylated. They also showed that there are interactions between TaqI, methylation levels, ethnicity, and tuberculosis susceptibility (29). Consequently, we can hypothesise that this SNP may serve as a marker of methylation for other "functional" polymorphisms in the VDR gene or in nearby genes. TaqI SNP is located in the exon 9 which encodes the ligand-binding region of the VDR (30). The DNA methylation and histone modifications in these regions can change the chromatin state from an open to a closed conformation. It could lead to transcriptional repression of these genes. The expression of genes involved in Vitamin D metabolism are deregulated in various chronic diseases, and these changes may be partially accredited to epigenetic modifications (31).

Like some other researchers (32), we have found negative association in our paediatric patients between 25OHD level and total IgE. In comparison with other studies (22), we saw no significant association between TaqI and ApaI and IgE. But we should emphasise that $70 \%$ of our children were atopic with elevated IgE level.

In agreement with many other studies $(1,13)$, we found no associations between genotypes and serum 25OHD. Interestingly, IL-10 levels were significantly low in asthmatics with TC and CT genotypes for TaqI and ApaI. WBC was significantly high with a trend toward a higher Neutrophils count in patients with TC and CC genotypes for both SNPs. IL-10 is widely expressed among innate and adaptive immune cells (33). It restricts the ability of antigen presenting cells to promote the differentiation and proliferation of $\mathrm{CD}^{+} \mathrm{T}$ cells, and it influences the initiation and progress of adaptive T cell responses. IL-10 also inhibits the expression of numerous pro-inflammatory cytokines, thus further suppressing the ability of effector $\mathrm{T}$ cells to prolong inflammatory responses (34). Matilainen et al. showed that the effect of $1 \alpha, 25(\mathrm{OH})_{2} \mathrm{D}_{3}$ on the expression of IL-10 is achieved through cyclic recruitment of VDR to Vitamin D response elements (VDREs) within a promoter region of the IL-10 gene (35). Up-regulation of IL-10 by vitamin D suppresses the innate immune response, in order to avoid the effects of long-lasting inflammation, such as tissue damage and development of chronic illnesses (36-39).

Based on our findings we can hypothesise that patients with specific genotypes for TaqI and ApaI have suppressed IL-10 production due to a decrease in expression of VDR. This can lead to the deregulation of innate immune responses and to the continuation of inflammatory processes. The increased levels of the neutrophils and WBC in patients with these SNPs support this interpretation. It may be possible to use these genotypes as predictive biomarkers of chronic asthma.

Over half of our patients were VDD, and low levels of 25OHD may be responsible for the suppression of their IL-10, due to insufficient production of the active form $1 \alpha, 25(\mathrm{OH})_{2} \mathrm{D}_{3}$ Sufficient $25 \mathrm{OHD}$ levels may be vital, since they influence local tissue concentrations of the active metabolite $(40,41)$. Ojaimi et al. have suggested that serum $25 \mathrm{OHD}$ levels as high as $120 \mathrm{nmol} / \mathrm{L}$ may be necessary for optimal immune function (42). This could explain why in our Vitamin D supplementation study (10) we did not observe any beneficial effects of vitamin D on asthma biomarkers in our patients. Only $20 \%$ of VDD subjects achieved $25 \mathrm{OHD}$ levels $>120 \mathrm{nmol} / \mathrm{L}$ after 15 weeks of supplementation with 2000 units each day. In the VDS group 63\% of the patients achieved these levels. It can partially explain why after supplementation the VDS group had significantly fewer days of school missed and fewer steroid requirements than all other groups (10). We could not make any conclusions regarding the genotypes' effects on different asthma parameters and biomarkers after supplementation, probably due to the small number of children in both groups. We should point out the importance of phenotypical differences in our patients. Two of the children (both female) were obese and VDD. Only one of them improved significantly after supplementation without achieving $25 \mathrm{OHD}$ level over $120 \mathrm{nmol} / \mathrm{L}$, and her genotype was TT for TaqI and ApaI. We hypothesise that in obesity-related asthma, genotypical investigation can be used to predict a beneficial response to vitamin $\mathrm{D}$ treatment. And we furthermore suggest that any benefit from vitamin $\mathrm{D}$ supplements can be achieved only in patients who have specific genotypes with particular asthma phenotypes. 
Patient selection might help clarify whether vitamin D can be useful for enhancing asthma therapy.

We admit that the main limitation of our pilot study is our limited sample size, but in a small country it is difficult to recruit a sufficient number of paediatric patients with uncontrolled asthma. In this paper we explored only two VDR polymorphisms without including others, such as FokI, BsmI and Tru9. We also limited our study to the IL-10 measurements, and we did not analyse other cytokines or VDR. But ours is a pioneering work in Irish paediatric asthmatic research, and we hope that it will open new horizons for future studies in this area.

In summary, we have revealed an association of TaqI and ApaI polymorphisms of the VDR gene with a susceptibility to uncontrolled asthma in a cohort of paediatric Irish patients. Also, we have shown that the patients with TC for TaqI, and CC and CT genotypes for ApaI have a significantly low level of IL-10 and increased WBC (neutrophils in particular). In our study we were the first to observe that TT and CC haplotypes were significantly associated with asthma in Irish children and could be potential biomarkers for paediatric asthma.

Further and more extensive functional studies will be necessary to confirm our findings in order to elucidate the underlying mechanisms in asthma that are related to vitamin D and VDR polymorphisms in specific asthma phenotypes.

\section{Acknowledgements}

This paper was supported by Research Grant from the Irish Research Council and from the National Children's Hospital Fundraising Foundation, Dublin, Ireland.

\section{Conflict of interest}

The authors declare that they have no conflict of interest.

\section{References}

1. Tizaoui K, Berraies A, Hamdi B, Kaabachi W, Hamzaoui K, Hamzaoui A. Association of Vitamin D Receptor Gene Polymorphisms with Asthma Risk: Systematic Review and Updated Meta-analysis of Case-Control Studies. Lung 2014; 192:955-65.

2. Iordanidou M, Paraskakis E, Giannakopoulou E, Tavridou A, Gentile G, Borro M, Simmaco M, Chatzimichael A, Bush A, Manolopoulos VG. Vitamin D receptor ApaI a allele is associated with better childhood asthma control and improvement in ability for daily activities. OMICS 2014; 18(11):673-81.

3. Menezes RJ, Cheney RT, Husain A, Tretiakova M, Loewen G, Johnson CS, Jayaprakash V, Moysich KB, Salgia R, Reid ME. Vitamin $\mathrm{D}$ receptor expression in normal, premalignant, and malignant human lung tissue. Cancer Epidemiol Biomarkers Prev 2008; 17(5):1104-10.

4. Bikle D. Extrarenal synthesis of 1,25-dihydroxyvitamin D and its health implications. In: Holick MF, editor. Nutrition and Health: Vitamin D. Humana Press; New York: 2010; 277-95.
5. Bikle D. Vitamin D: newly discovered actions require reconsideration of physiologic requirements. Trends Endocrinol Metab 2010; 21(6): 375-84.

6. Damera G, Fogle HW, Lim P, et al. Vitamin D inhibits growth of human airway smooth muscle cells through growth factor-induced phosphorylation of retinoblastoma protein and checkpoint kinase 1. Br J Pharmacol 2009; 158:1429-41.

7. Gordon CM, Feldman HA, Sinclair L, et al. Prevalence of vitamin D deficiency among healthy infants and toddlers. Arch Pediatr Adolesc Med 2008; 162:505-12.

8. Kumar J, Muntner P, Kaskel FJ, et al. Prevalence and Associations of 25-Hydroxyvitamin D Deficiency in US Children: NHANES 2001-2004. Pediatrics 2009; 123:362-70.

9. Brehm JM, Schuemann B, Fuhlbrigge AL, et al. Serum vitamin $\mathrm{D}$ levels and severe asthma exacerbations in the Childhood Asthma Management Program study. J Allergy Clin Immunol 2010; 126(1):52-8.e5.

10. Kerley C, Hutchinson K, Cormican L, Faul J, Greally P, Coghlan D, Elnazir B, Vitamin D3 for uncontrolled childhood asthma: A pilot study. Pediatric Allergy and Immunology 2016; 27:404-12.

11. Miyamoto K, Kesterson RA, Yamamoto H, Taketani Y, Nishiwaki E, Tatsumi S, et al. Structural organization of the human vitamin D receptor chromosomal gene and its promoter. Mol Endocrinol 1997; 11:1165-79.

12. Han JC, Du J, Zhang YJ, Qi GB, Li HB, Zhang YJ, Yu XI. Vitamin D receptor polymorphisms may contribute to asthma risk. J Asthma 2016; 53(8):790-800.

13. Zhao DD, Yu DD, Ren QQ, Dong B, Zhao F, Sun YH. Association of vitamin $\mathrm{D}$ receptor gene polymorphisms with susceptibility to childhood asthma: A meta-analysis. Pediatr Pulmonol 2017; 52:423-9. doi: 10.1002/ppul.23548

14. Papadopoulou A, Kouis P, Middleton N, Kolokotroni O, Karpathios T, Nicolaidou P, Yiallouros PK. Association of vitamin D receptor gene polymorphisms and vitamin D levels with asthma and atopy in Cypriot adolescents: a case-control study. Multidisciplinary Respiratory Medicine 2015; 10:26.

15. Ismail MF, Elnady HG, Fouda EM. Genetic variants in vitamin D pathway in Egyptian asthmatic children: a pilot study. Hum Immunol 2013; 74:1659-64.

16. Raby BA, Lazarus R, Silverman EK, Lake S, Lange C, Wjst M, et al. Association of vitamin D receptor gene polymorphisms with childhood and adult asthma. Am J Respir Crit Care Med 2004; 170:1057-65.

17. Uitterlinden AG, Fang Y, Van Meurs JB, Pols HA, Van Leeuwen JP. Genetics and biology of vitamin D receptor polymorphisms. Gene 2004; 338:143-56.

18. Pludowski P, Holick MF, Pilz S, Wagner CL, Hollis BW, Grant WB, et al.Vitamin D effects on musculoskeletal health, immunity, autoimmunity, cardiovascular disease, cancer, fertility, pregnancy, dementia and mortality-review of recent evidence. Autoimmun Rev 2013; 12:976-89.

19. Jolliffe D, Walton R, Griffiths C, Martineau A. Single nucleotide polymorphisms in the vitamin $\mathrm{D}$ pathway associating with circulating concentrations of vitamin D metabolites and non-skeletal health outcomes: Review of genetic association studies. J. Steroid Biochem Mol Biol 2016; 164:18-29.

20. Global Initiative for Asthma. Global strategy for asthma management and prevention. 2011 (Accessed June 2012). Available from: www.ginasthma.com. 
21. (No authors listed) Standardized lung function testing. Official statement of the European Respiratory Society. Eur Respir J Suppl 1993;16:1-100.

22. Poon AH, Laprise C, Lemire M, Montpetit A, Sinnett D, Schurr $\mathrm{E}$, et al. Association of vitamin $\mathrm{D}$ receptor genetic variants with susceptibility to asthma and atopy. Am J Respir Crit Care Med 2004; 170:967-73.

23. Saadi A, Gao G, Li H, Wei C, Gong Y, Liu Q. Association study between vitamin $\mathrm{D}$ receptor gene polymorphisms and asthma in the Chinese Han population: a case-control study. BMC Med Genet 2009;10:71.

24. Morrison NA, Qi JC, Tokita A, et al. Prediction of bone density from vitamin D receptor alleles. Nature 1994; 367:284-7.

25. Fang Y, van Meurs JB, D'Alesio A., et al. Promoter and 3'-untranslated-region haplotypes in the vitamin $\mathrm{D}$ receptor gene predispose to osteoporotic fracture: the Rotterdam study. The American Journal of Human Genetics 2005; 77(5):807-23.

26. Whitfield GK, Remus LS, Jurutka PW, Zitzer H, Oza AK, et al. Functionally relevant polymorphisms in the human nuclear vitamin D receptor gene. Mol Cell Endocrinol 2001; 177:145-59.

27. Ingles SA, Haile RW, Henderson BE, Kolonel LN, Nakaichi G, Shi CY, Yu MC, Ross RK, Coetzee GA: Strength of linkage disequilibrium between two vitamin $\mathrm{D}$ receptor markers in five ethnic groups: implications for association studies. Cancer Epidemiol Biomarkers Prev 1997; 6:93-8.

28. Jurutka PW, Whitfield GK, Hsieh JC, Thompson PD, Haussler CA, Haussler MR. Molecular nature of the vitamin D receptor and its role in regulation of gene expression. Reviews in Endocrine and Metabolic Disorders 2001; 2(2):203-16.

29. Andraos C, Koorsen G, Knight JC, Bornman L. Vitamin D receptor gene methylation is associated with ethnicity, tuberculosis, and TaqI polymorphism. Hum Immunol 2011; 72:262-8.

30. Zmuda JM, Cauley JA, Ferrell RE. Molecular epidemiology of vitamin D receptor gene variants. Epidemiol Rev 2000; 22:203-17.

31. Fetahu IS, Höbaus J, Kállay E. Vitamin D and the epigenome. Front Physiol 2014; 5:164.

32. Sharief S, Jariwala S, Kumar J, Muntner P, Melamed ML. Vitamin $\mathrm{D}$ levels and food and environmental allergies in the United States: results from the National Health and Nutrition Examination Survey 2005-2006. J Allergy Clin Immunol 2011; 127(5):1195-202.

33. O'Garra A, Vieira P. T(H) 1 cells control themselves by producing interleukin-10. Nat Rev Immunol 2007; 76:425-8.

34. Maynard CL, Weaver CT. Diversity in the contribution of interleukin-10 to T-cell-mediated immune regulation. Immunol Rev 2008; 226:219-33.

35. Matilainen JM, Husso T, Toropainen S, Seuter S, Mikko Turunen M, Gynther P, Ylä-Herttuala S, Carlberg C, Väisänen S. Primary effect of $1 \alpha, 25(\mathrm{OH}) 2 \mathrm{D} 3$ on IL-10 expression in monocytes is shortterm down-regulation. Biochim Biophys Acta 2010; 1803:1276-86.

36. Barrat FJ, Cua DJ, Boonstra A, Richards DF, Crain C, Savelkoul HF, de Waal-Malefyt R, Coffman RL, Hawrylowicz CM, O'Garra A. In vitro generation of interleukin 10-producing regulatory CD4(+) T cells is induced by immunosuppressive drugs and inhibited by $\mathrm{T}$ helper type 1 (Th1)- and Th2-inducing cytokines. J Exp Med 2002; 195:603-16.

37. Penna G, Adorini L. 1 $\alpha, 25$-dihydroxyvitamin D3 inhibits differentiation, maturation, activation, and survival of dendritic cells leading to impaired alloreactive T cell activation. J Immunol 2000; 164:2405-11.

38. Heine G, Niesner U, Chang HD, Steinmeyer A, Zügel U, Zuberbier T, Radbruch A, Worm M. 1,25-dihydroxyvitamin D3 promotes IL-10 production in human B cells. Eur J Immunol 2008; 38:2210-8

39. Urry Z, Chambers ES, Xystrakis E, Dimeloe S, Richards DF, Gabryšová $\mathrm{L}$, et al. The role of $1 \alpha, 25$-dihydroxyvitamin $\mathrm{D} 3$ and cytokines in the promotion of distinct Foxp3+ and IL-10+ CD4+ T cells. Eur J Immunol 2012; 42(10):2697-708.

40. Hewison M. Antibacterial effects of vitamin D. Nat Rev Endocrinol 2011; 7(6):337-45.

41. Zella LA, Kim S, Shevde NK, Pike JW. Enhancers located within two introns of the vitamin $\mathrm{D}$ receptor gene mediate transcriptional autoregulation by 1,25-dihydroxyvitamin D3. Mol Endocrinol 2006; 20:1231-47.

42. Ojaimi S, Skinner NA, Strauss BJ, Sundararajan V, Woolley I, Visvanathan $\mathrm{K}$. Vitamin D deficiency impacts on expression of tolllike receptor-2 and cytokine profile: a pilot study. J Transl Med 2013; 11:176. 